\title{
Kaj se lahko iz epidemije covida-19 naučimo v socialnem delu?
}

V Sloveniji je bila marca 2020 zaradi virusa covid-19 prvič razglašena epidemija. Podobno kot drugod po svetu smo se skoraj čez noč znašli v izrednih razmerah, za katere si je najbrž le redkokdo predstavljal, da bodo trajale več kot dve leti. Spremenjene razmere, ki so jih določali predvsem ukrepi medicinske stroke z namenom preprečevanja širjenja virusa in varovanja fizičnega zdravja, so zahtevale drugačen način življenja oz. sobivanja tako v vsakdanjem in zasebnem kot tudi v delovnem življenju. Zato je za številne ljudi to pomenilo tudi nove izzive in stiske oz. povečalo že obstoječe. Na to že od začetka epidemije opozarjajo tudi socialne delavke, ki so po navadi med prvimi v stiku z ljudmi, ki potrebujejo podporo in pomoč pri reševanju psihosocialnih izzivov. Kljub temu pa je epidemija na lokalni ravni pokazala na (ne)vključenost socialnih delavk v načrtovanje ukrepov, na nacionalni in mednarodni ravni pa na spregledanost znanosti in stroke socialnega dela kot kompetentne sogovornice pri reševanju sodobnih (socialnih) izzivov družbe.

Na Fakulteti za socialno delo Univerze v Ljubljani smo želeli preveriti, kaj se je v času epidemije dogajalo tako na področju izobraževanja za socialno delo kot tudi v praksi socialnega dela. Nekatere zaposlene (Leskošek, Mešl, Kodele, Šabić, Rape Žiberna) smo tako že v času prvega vala epidemije ali takoj po njem začele zbirati podatke o stanju (tako z zbiranjem dnevniških zapisov strokovnih delavk kot tudi z izvedbo spletne ankete med študentkami ter mentoricami prakse). $\mathrm{V}$ drugem valu epidemije pa so nekatere raziskovalke (pod vodstvom Leskošek in Mešl) izvedle še intervjuje in anketiranje zaposlenih na centrih za socialno delo. Tako je leta 2020 nastala bogata zbirka podatkov o začetnem odzivanju socialnega dela na izredne razmere v času covida-19, pa tudi dober popis izzivov, ki so se pojavili v tem obdobju.

Rezultate omenjenih raziskav smo raziskovalke večkrat predstavile na različnih dogodkih, seminarjih, konferencah ipd. Zato smo zaposlene na fakulteti od socialnih delavk začele dobivati pobude, da bi o dogajanju na področju socialnega dela in dobrih praksah v času epidemije v Sloveniji želeli imeti kaj dokumentirano, saj se je tudi po njihovem mnenju o vlogi socialnega dela $\mathrm{v}$ času pandemije covida-19 premalo oz. skoraj nič govorilo. Zato sva se odločili urediti tematsko številko, ki je pred vami. Z njo sva po eni strani želeli opozoriti na to, da je socialno delo v Sloveniji, v času epidemije, po krivici spregledan partner pri dogovarjanju o čim ustreznejših ukrepih in njihovi implementaciji, po drugi strani pa prikazati tudi dobre prakse, ki so se v tem specifičnem obdobju udejanjale. S tem pa ponuditi tako izobraževanju kot tudi znanosti in praksi socialnega dela refleksije in ideje za delo v prihodnjih izrednih razmerah. 
V tematski številki je tako zbranih osem prispevkov raziskovalk in socialnih delavk na področju socialnega dela, ki opisujejo pogled na dogajanje (izzive pa tudi nove prakse in priložnosti za prihodnost) v času epidemije.

Alenka Gril in Mojca Šeme se tako v prvem članku z naslovom Vloga socialnega dela vizrednih razmerah sprašujeta, kako se lahko socialno delo vključuje v odpravljanje posledic različnih vrst katastrof, ki povzročajo izredne razmere $\mathrm{v}$ družbi. S pomočjo analize skupnih in specifičnih značilnosti problemov, $\mathrm{S}$ katerimi se srečujejo ljudje v izrednih razmerah, ter različnih pristopov in metod socialnega dela strnita izkušnje učinkovitega socialnega dela v različnih vrstah katastrof in oblikujeta smernice za socialno delo v izrednih razmerah v prihodnje, pa tudi v aktualni pandemiji covida-19. Posebno pozornost namenita obravnavi pomoči in podpore socialnim delavkam in drugim ljudem $\mathrm{v}$ poklicih pomoči, ki so $\mathrm{v}$ primerih izrednih razmer še bolj obremenjeni.

$\mathrm{Z}$ osredotočenostjo na socialne delavke nato nadaljuje Ana M. Sobočan v članku Etična socialnodelovna praksa v pandemičnem času. Prispevek predstavlja preplet teoretskih konceptov, doslej opravljenih (mednarodnih) raziskav in ugotovitev o etičnih dilemah v socialnem delu, tudi v času covida-19. Prikaže tudi šest dilemskih polj in jim doda priporočila za odziv na etične dileme, $s$ katerimi se socialne delavke srečujejo v času covida-19. Ta priporočila so za socialne delavke uporabna tudi na splošno in ne le v času izrednih razmer.

Nina Mešl in Vesna Leskošek v prispevku z naslovom Delovanje centrov za socialno delo $v$ času prvega in drugega vala epidemije covida-19 predstavita pred kratkim opravljeno kompleksno raziskavo o socialnem delu v času covida-19 v Sloveniji. Na podlagi ugotovitev raziskave in ob podpori znanstvenih izhodišč za socialno delo v času izrednih razmer predstavita odziv centrov na spremembe $v$ prvem in drugem valu epidemije ter dva med seboj povezana sklopa smernic za delo socialnih služb v času izrednih razmer. Poudarita velik pomen organizacije in pomembnost tako izboljšanja delovnega okolja in delovnih razmer $\mathrm{v}$ času izrednih razmer kot tudi skrbi za povezanost in komunikacijo med zaposlenimi.

V prispevku Praksa na Fakulteti za socialno delo v času izrednih razmer: izkušnje študentk in mentoric v prvem valu epidemije covida-19 avtorice Tadeja Kodele, Klavdija Kustec in Tamara Rape Žiberna prikažemo prve vtise ob spremenjenih razmerah za opravljanje praktičnega usposabljanja na področju socialnega dela. Raziskava je pokazala, da so se študentke v tem obdobju srečevale predvsem z izzivi, ki so bili povezani z nemožnostmi za sodelovanje $\mathrm{z}$ uporabniki, in z dodatno obremenjenostjo zaradi prilagoditev študijskega procesa, mentorice pa z izzivi, kako zagotavljati kakovostno mentorstvo in omogočati pričakovane izkušnje v takšnih okoliščinah. Kljub temu pa so zaradi spremenjene situacije študentke na praksi pridobile nova znanja, tako vsebinska kot tudi znanja za uporabo informacijsko-komunikacijske tehnologije. Pokaže se tudi velika pomembnost ustrezne podpore mentoric.

$\mathrm{V}$ drugem delu številke pa $\mathrm{v}$ zanimivem eseju in poročilih iz prakse lahko preberemo o dogajanju v času epidemije, tako na področju šolstva, centrov za socialno delo kot tudi nevladnih organizacij. 
V eseju z naslovom Leto nemoči: »Pozabljeni« učenci v času epidemije Daniela Janušič ob kritičnem razmisleku zelo nazorno opiše stiske tako otrok in staršev kot tudi učiteljev in svetovalnih delavk na osnovni šoli v času covida-19. Gre za čas, ko so na nekaterih osnovnih šolah menili, da je delo svetovalne službe $v$ času t. i. »šolanja na daljavo « nepotrebno (ker učencev ni v šolskih prostorih) in so ponekod svetovalne delavke pošiljali na dopust ali čakanje na delo. Pokazalo se je prav nasprotno, da je v takšnih (izrednih) razmerah socialno delo v osnovnih šolah še toliko potrebnejše, s svojimi znanji individualnega načrtovanja, razumevanja konteksta in specifik posameznih situacij ter soustvarjanja izvedljivih, konkretnim situacijam prilagojenih odgovorov na izzive, ki so se na novo pojavili, in na obstoječe izzive, ki jih je situacija epidemije povečala.

Katja Čelič nas v prispevku z naslovom Koordinirana obravnava v skupnosti $v$ času epidemije covida-19 opozori na to, da je epidemija poleg več novih izzivov ter povečanja obstoječih strokovnim delavkam koordinirane obravnave, ki delujejo na centrih za socialno delo, prinesla tudi zavedanje o medsebojni soodvisnosti strokovnjakov različnih služb, ki pomagajo ljudem v stiskah, ter o pomembnosti medsebojne podpore tudi pri ohranjanju in krepitvi socialnega dela $v$ centrih za socialno delo.

V prispevku Maje Gorenc Šulc z naslovom Socialno delo z uporabniki Območnega združenja Rdečega križa Novo mesto v času razglašene epidemije covida-19 lahko preberemo, kako so se v nevladni organizaciji, sicer vajeni delovanja $\mathrm{v}$ izrednih razmerah, odzivali na zaznane nove in povečane potrebe zaposlenih, predvsem pa tudi različnih skupin uporabnikov njihovih storitev. V celotnem prispevku avtorica opisuje pomembnost tako socialnega dela v lokalnem okolju (pri spodbujanju in krepitvi solidarnosti, sosedske pomoči) kot tudi dobrega medsebojnega sodelovanja organizacij in institucij za zagotavljanje podpore in potrebne pomoči, pri čemer ima lahko tudi socialno delo pomembno vlogo.

Številko sklene še prispevek iz tujine z naslovom Social changes and challenges in (post-)pandemic times for social professions, ki na podlagi mednarodnega srečanja z naslovom Socialne spremembe in izzivi v času (post)pandemije, ki je potekalo poleti 2021 prek spleta v organizaciji mednarodne pisarne Protestantske univerze za uporabne znanosti iz Bochuma v Nemčiji, na kratko predstavi situacijo v času pandemije covida-19 v štirih državah na treh celinah. Avtorji ugotavljajo, da je kljub nekaterim podobnostim pandemija različno prizadela države, skupine prebivalstva pa tudi različne stroke, kljub temu pa je srečanje pokazalo podobne ugotovitve iz različnih držav: a) povečanje socialne neenakosti in vidnosti te neenakosti, b) povečanje nasilja $v$ družini in nasilja na podlagi spola, c) veliko izzivov, povezanih s socialno izolacijo, d) pojav številnih novih izzivov za sistem socialnega varstva in na področju duševnega zdravja.

Ob koncu le še nekaj kratkih pojasnil. Ker tako v socialnem delu kot tudi v tej tematski številki predstavljenih raziskavah prevladujejo osebe, ki so se identificirale z ženskim spolom, v prispevkih uporabljamo večinoma žensko slovnično obliko. Pri tem pa slovnični spol uporabljamo vključujoče in se nanaša navse spole in spolne izraze. Izraz epidemija uporabljamo, kadar mislimo na situacijo, stanje v Sloveniji, izraz pandemija pa, ko pišemo o dogajanju na širšem geografskem območju (torej ne zgolj na področju Slovenije). 
Vabljeni k prebiranju prispevkov v upanju, da bo tematska številka pripomogla h krepitvi moči socialnega dela ter socialnih delavk tako $v$ času izrednih razmer, ki smo jim priče v času covida-19, kot tudi sicer. Še posebej ob različnih katastrofah je namreč pomembno, da socialno delo ne zgolj obstane, pač pa lahko s svojim odzivanjem na zaznane (nove) potrebe (posameznikov, skupin in skupnosti) okrepi svoj glas in prispevek pri pomembnih odločitvah, sprejetih v času izrednih razmer, kot smo jim priče tudi v času covida-19.

Tamara Rape Žiberna in Tadeja Kodele

Oktober 2021 